\title{
Adsorption Studies of Lead by Enteromorpha Algae and Its Silicates Bonded Material
}

\author{
Hassan H. Hammud, ${ }^{1,2}$ Ali El-Shaar, ${ }^{2}$ Essam Khamis, ${ }^{3}$ and El-Sayed Mansour ${ }^{4}$ \\ ${ }^{1}$ Chemistry Department, Faculty of Science, King Faisal University, Al-Ahsa 31982, Saudi Arabia \\ ${ }^{2}$ Chemistry Department, Faculty of Science, Beirut Arab University, Beirut, Lebanon \\ ${ }^{3}$ City of Scientific Research \& Technological Applications, Borg Al Arab, Alexandria, Egypt \\ ${ }^{4}$ Faculty of Science, Alexandria University, Alexandria, Egypt \\ Correspondence should be addressed to Hassan H. Hammud; hhammud@yahoo.com
}

Received 31 May 2014; Revised 16 September 2014; Accepted 22 September 2014; Published 5 November 2014

Academic Editor: Ioannis Konstantinou

Copyright ( 2014 Hassan H. Hammud et al. This is an open access article distributed under the Creative Commons Attribution License, which permits unrestricted use, distribution, and reproduction in any medium, provided the original work is properly cited.

Lead adsorption by green Enteromorpha algae was studied. Adsorption capacity was $83.8 \mathrm{mg} / \mathrm{g}$ at pH 3.0 with algae (E) and $1433.5 \mathrm{mg} / \mathrm{g}$ for silicates modified algae (EM). FTIR and thermal analysis of algae materials were studied. Thomas and YoonNelson column model were best for adsorbent (E) and algae after reflux (ER) and Yan model for (EM) with capacity 76.2, 71.1, and $982.5 \mathrm{mg} / \mathrm{g}$, respectively. (ER) and (EM) show less swelling and better flow rate control than (E). Nonlinear methods are more appropriate technique. Error function calculations proved valuable for predicting the best adsorption isotherms, kinetics, and column models.

\section{Introduction}

The contamination of wastewater and soil with heavy metal ions is a complex problem, since these metals are toxic in both their elemental and chemically combined forms. Natural water is contaminated with several heavy metals due to their widespread use in industry and agriculture arising mostly from mining wastes and industrial discharges. From an environmental protection point of view, heavy metal ions should be removed at the source in order to avoid pollution of natural waters and subsequent metal accumulation in the food chain. In fact, removal of this contamination has received much attention in recent years $[1,2]$.

Lead being one of the "big three" toxic heavy metals, it is of profound concern as a toxic waste and contaminant of surface waters as it becomes concentrated throughout the food chain to humans [3]. Lead damages different body organs (central and peripheral nervous systems and kidney); also, lead has a teratogenic effect, causing stillbirth in women and affecting the fetus [4].

Conventional methods for removal are chemical precipitation, chemical oxidation, chemical reduction, ion exchange, filtration, electrochemical treatment, and evaporation $[5,6]$. These methods often are very expensive.

Alternative method for heavy metal removal was developed in the last past decade and known as biosorption. Marine algae, an abundant renewable natural biomass, have been used as dead nonliving materials for removal of heavy metals [7, 8]. In addition, algae were found accumulating heavy metal in their habitat and are thus used as heavy metal pollution monitors in fresh and salty water such as river, sea, and ocean. They have been also used in on-site bioremediation of polluted natural water $[9,10]$.

Furthermore, the search for a low-cost and easily available adsorbent has led to the investigation of materials of agricultural and biological origin (bacteria, fungi, yeast, and algae can remove heavy metals from a solution in considerable quantities), along with industrial byproducts, as potential metal sorbents. These low-cost and nonconventional adsorbents include agricultural wastes like natural compost, Irish peanut, peanut shell, coconut shell, bone, and biomass such as Aspergillus terreus and Mucus remanianus, polymerized onion skin with formaldehyde and EDTA, modified cellulosic material, and natural materials such as hair and cattails 
(Typha plant), waste wool, peanut skin, modified barks, barely straw, low rank coal, soils, human hair, peat moss, fertilizer waste slurry, waste tire rubber, and tea leaves [1122].

Biosorption process for metal removal has a performance comparable to a commercial competitor, ion exchange treatment. While commercial ion exchange resins are rather costly, the price tag of biosorbents can be an order of magnitude cheaper (1/10 of the ion exchange resin cost) [23, 24].

Some of the key features of biosorption compared to conventional processes include competitive performance, heavy metal selectivity, cost-effectiveness, regenerative, process equipment known, no sludge generation, and metal recovery possible [25].

In the literature, there are divergent mechanisms explaining the metal uptake by marine algae. A semispeculative model of the structure of the cell walls of the algae has been proposed recently. This could suggest that there are two common moieties to which the uptake ability of taxonomically different algal biomass was attributed: sulfated ester polysaccharides (fucoidans, carrageenans, and galatians and xylans) and polyuronides (galacturonic, glucuronic, guluronic, and mannuronic acids). The sulfate and carboxylic acid groups could be considered as responsible for the bulk of metal uptake sorption [26]. In general, the algae are very soft, with the tendency to disintegrate which prevents the follow-up experiments even in laboratory column [27]. Also, the small size of algae particles with low density, mechanical strength, and rigidity affects the performance of algae. Immobilization of algae within a matrix (e.g., silicates) through chemical pretreatment can overcome these problems and allow industrial application [28-30].

The present work is focused on the ability of green algae Enteromorpha collected from Lebanese coast to adsorb $\mathrm{Pb}^{2+}$ from aqueous medium at $25^{\circ} \mathrm{C}$. Comparative studies are made between nonmodified Enteromorpha algae (E), algae residue after reflux (ER), and algae modified with silicates (EM).

Optimum conditions for adsorption (mass, $\mathrm{pH}$, concentration, and residence time) are considered in batch experiments. Also column application for algae materials was studied for maximum capacity per one gram.

Infrared spectra and thermogravimetric analysis of Enteromorpha algae were detected before and after adsorption.

\section{Theoretical}

2.1. Isotherm and Column Models. The equations and parameters of the isotherms adsorption models (Langmuir, Freundlich, Redlich-Peterson, Temkin, Elovich, and DubininRadushkevich), column kinetic models (Thomas, YoonNelson, and Yan model) are described in detail in our previous work [31-34] and references therein, Tables 1 and 2.

In general all calculations are based on the following two terms: $q_{e}(\mathrm{mg} / \mathrm{g})$, the equilibrium metal uptake (mass of adsorbed pollutant (mg) per mass of adsorbent $(\mathrm{g})$ ) and $C_{e}(\mathrm{mg} / \mathrm{L})$ or $(\mathrm{ppm})$, the equilibrium ion concentration of pollutant remaining in solution.
TABLE 1: Nonlinear equations of different adsorption isotherms.

\begin{tabular}{ll}
\hline Isotherm model & Equation \\
\hline Langmuir & $Q_{e}=\frac{Q^{o} K_{L} C_{e}}{1+K_{L} C_{e}}$ \\
\hline Freundlich & $Q_{e}=K_{F}\left(C_{e}\right)^{1 / n}$ \\
\hline Redlich-Peterson & $Q_{e}=\frac{A_{\mathrm{RP}} C_{e}}{1+K_{\mathrm{RP}} C_{e}^{\beta}}$ \\
\hline Elovich & $Q_{e}=B_{T} \ln \left(K_{T}\right)+B_{T} \ln \left(C_{e}\right)$ \\
\hline Dubinin-Radushkevich & $\frac{Q_{e}}{Q_{E}}=K_{E} C_{e} e^{-\left(Q_{e} / Q_{E}\right)}$ \\
\hline
\end{tabular}

2.2. Error Analysis. The computational part of the obtained experimental measurements is introduced. To obtain the curve which best fits the data in least-squares sense, the following minimization problem is solved by calculating error parameters $R^{2}, \chi^{2}$, and SSE. Error calculations were used for the fitting quality of the isotherm and column models to the experimental data, Table 3 [31-34], where $x$ data $_{i}$ and $y$ data $_{i}$ are the experimental measurements and $f\left(x, x\right.$ data $\left._{i}\right)$ is a function of the linear or nonlinear curve proposed to fit the given data. The $x$ data $_{i}$ is the equilibrium concentration $C_{e}$ and $y$ data $_{i}$ is dependent on $q_{e}$.

The squared correlation coefficient $R^{2}$ is defined in Table 3, $R$ being the correlation between the experimental data and the used model, where $X=y$ data $_{i}=y_{e, \exp }$ and $Y=f\left(x, x\right.$ data $\left._{i}\right)=y_{e, \text { cal }}$.

The sum of squares of errors SSE and chi-square test $\chi^{2}$ depend on the total deviation of the calculated values from the fit to the experimental values in Table 3.

If data from the model are similar to the experimental data, $\chi^{2}$ and SSE will be a small number. On the other hand, the closer $R^{2}$ value to 1.00 the better is the fitting and the more suitable is the model. Thus, the best model chosen in each case is the one giving highest $R^{2}$ and lowest SSE and $\chi^{2}$.

\section{Experimental}

3.1. Chemicals. All reagents are from Fluka: lead nitrate $\mathrm{Pb}\left(\mathrm{NO}_{3}\right)_{2}$, sodium silicates for chemical modification of algae, sodium acetate, and acetic acid for preparation of acetate buffer.

3.2. Algae Collection. The raw algae Enteromorpha intestinalis was harvested from the Lebanese coast, washed with tap and deionized water in order to remove extra salts, sun dried, and grounded to particle size ( 0.5 mesh). Finally, the fine powder is oven dried at $60^{\circ} \mathrm{C}$ for 24 hours to give algae material (E) for further use in metal uptake study.

\subsection{Preparation of Algae Residue (ER), Modified Algae (EM), and Swedish Wood Sawdust (SWS)}

3.3.1. Preparation of Algae Residue Material (ER). Enteromorpha algae $(J)$ powder $10 \mathrm{gm}$ was refluxed in deionised 
TABLE 2: Nonlinear and linear equations of different kinetic column models.

\begin{tabular}{lll}
\hline Kinetic models & Nonlinear equations & Linear equations \\
\hline Thomas model & $\frac{C_{e}}{C_{o}}=\frac{1}{1+\exp \left(\left(K_{\mathrm{Th}} / Q\right)\left(q_{\mathrm{T}} m-C_{o} V_{\mathrm{eff}}\right)\right)}$ & $\ln \left[\left(\frac{C_{o}}{C_{e}}\right)-1\right]=\left(\frac{K_{\mathrm{Th}} q_{\mathrm{T}} M}{\mathrm{Q}}\right)-\left(K_{\mathrm{Th}} C_{o} t\right)$ \\
\hline Yoon-Nelson model & $\frac{C_{e}}{C_{o}}=\frac{1}{1+e^{K_{\mathrm{YN}}(\tau-t)}}$ & $\ln \left(\frac{C_{e}}{C_{o}-C_{e}}\right)=K_{\mathrm{YN}} t-\tau K_{\mathrm{YN}}$ \\
\hline Yan et al. model [42] & $\frac{C_{e}}{C_{o}}=1-\frac{1}{1+\left(Q^{2} t / K_{y} q_{y} m\right)^{K_{y} C_{o} / \mathrm{Q}}}$ & $\ln \left[\left(\frac{C_{e}}{C_{o}-C_{e}}\right)\right]=\left(\frac{K_{y} C_{o}}{Q}\right) \ln \left(\frac{Q^{2}}{K_{y} q_{y} m}\right)+\left(\frac{K_{y} C_{o}}{Q}\right) \ln t$ \\
\hline
\end{tabular}

TABLE 3: Error function and squared correlation coefficient for best-fitting model estimation.

$$
R^{2}=\frac{\left(\sum(X-\bar{X})(Y-\bar{Y})\right)^{2}}{\sum(X-\bar{X})^{2}(Y-\bar{Y})^{2}} \quad \text { Chi-square }=\chi^{2}=\sum \frac{\left(y_{e, \exp }-y_{e, \mathrm{cal}}\right)^{2}}{y_{e, \mathrm{cal}}} \quad \operatorname{SSE}=\sum\left(y_{e, \exp }-y_{e, \mathrm{cal}}\right)^{2}
$$

water $100 \mathrm{~mL}$ for $15 \mathrm{~min}$ giving green suspension; the residue material was separated from the green solution by filtration and then dried to give Enteromorpha algae after reflux (ER) in $80 \%$ yield.

3.3.2. Preparation of Swedish Wood Sawdust (SWS). Swedish wood sawdust was ground to 0.5 mesh particle size washed with deionized water and dried similar to algae.

\subsubsection{Preparation of Sodium Silicate Algae Material (EM).} Enteromorpha powder (E) was washed with $\mathrm{HCl}(0.1 \mathrm{M})$ and water, respectively. The material was then separated by centrifuging. Sulfuric acid $(120 \mathrm{~mL}, 5 \%)$ was mixed with enough sodium silicate $\left(\mathrm{Na}_{2} \mathrm{SiO}_{3}\right)(6 \%)$ to raise the $\mathrm{pH}$ of the solution to 2.0. At pH 2.0, the washed biomass was added to the solution and stirred for 10 minutes. Additional amount of sodium silicate $(6 \%)$ was then slowly added to raise the $\mathrm{pH}$ of the solution to 7.0. The resulting polymer gel was washed with water and oven dried at $60^{\circ} \mathrm{C}$ for one week. The dried polymer was ground by mortar and pestle and sieved to be ready for further application [34].

3.4. Equipment and Instruments. The potentiometric measurements were carried out using Denver Instrument Model $225 \mathrm{pH}$-ion selective electrode meter fitted with a combined glass electrode (reading to $\pm 0.01 \mathrm{pH}$ unit). The reaction flask was kept constant at $25^{\circ} \mathrm{C}\left( \pm 0.1^{\circ} \mathrm{C}\right)$ by using a thermostat Model Heto HMT 200. The shaker (Wiggen Hauser OS-150, Germany) and centrifuge (Sigma 203) were used for agitation experiment. Lead content was analyzed using Buck Scientific Atomic absorption spectrometer. Infrared data were collected on a Shimadzu 8300 FTIR spectrophotometer using $\mathrm{KBr}$ pellet method. Thermogravimetric-differential scanning calorimetry (TG-DSC) curve was recorded on SETARAM LABSYS thermal analyzer in the flow of $\mathrm{N}_{2}$ within the 25$900^{\circ} \mathrm{C}$ temperature range, with a heating rate of $3^{\circ} \mathrm{C} / \mathrm{min}[31-$ 33].

3.5. Effect of Mass of Algae. The effect of mass of algae (E) on metal uptake was studied in batch system. $25 \mathrm{~mL}$ solution of $300 \mathrm{ppm}$ lead (at pH 4.00) in $50 \mathrm{~mL}$ Erlenmeyer flask was shaken with different masses of algae for $2 \mathrm{~min}$ at 200 r.p.m and left to stand for $24 \mathrm{hrs}$ in water bath at $25^{\circ} \mathrm{C}$ and then analyzed for the remaining lead [35].

3.6. $p H$ Effect. The mass of algae (E) used in this experiment is the optimum mass $0.3 \mathrm{~g}$ done in batch system using $50 \mathrm{~mL}$ Erlenmeyer flasks with a reaction volume of $25 \mathrm{~mL}$ lead solution $(300 \mathrm{mg} / \mathrm{L})$ at $25^{\circ} \mathrm{C}$. The mixture was shaken for 2 min (at 200 r.p.m) and left to stand for 24 hrs, at different pH using hydrochloric acid, sodium acetate buffer, and sodium hydroxide to cover the $\mathrm{pH}$ range 3.0-7.5 (3, 3.6, 4, 5, 6.08, 7.08, and 7.50$)$. In this experiment the $\mathrm{pH}$ value does not exceed 7.50 due to the precipitation of lead as lead hydroxide [36].

3.7. Effect of Lead Concentration. This experiment was done as above at only pH 3.0 (optimum value) using sodium acetate buffer but with different lead concentrations $(10,25,50,100$, 150, 200, 250, 300, 400, 500, and 1000 ppm).

3.8. Effect of Residence Time. This experiment was done at $25^{\circ} \mathrm{C}$ with $25 \mathrm{~mL}$ lead (200 ppm) and $0.3 \mathrm{~g}$ algae (E) in $50 \mathrm{~mL}$ Erlenmeyer flasks at pH 3.0 (using sodium acetate buffer) and shaken at 200 r.p.m for 2 minutes with variable standing time $(2,5,10,15,20,30,45,60,90$, and 120 minutes) [36].

3.9. Swelling Characteristics. Swelling characteristics (distention index, swelling ratio, and volume of absorbed solvent) were obtained from the weights and volumes of dry and swollen particles for algae alone (E), algae residue after reflux (ER), algae modified with silicates (EM), and Swedish wood sawdust (SWS). Dry particles were swollen in cylinders with deionized water and degassed under lower pressure. The volume was measured after periodically till two hours [27].

The distention index (DI) was calculated from the ratio $V_{s} / W_{D}$, where $V_{s}$ is the volume of the particles after swelling and $W_{D}$ is the weight of the dry particles. The swelling ratio is $W_{s} / W_{D}$, where $W_{s}$ is the weight of swollen particles. The volume of absorbed solvent $\left(V_{\mathrm{AS}}\right)$ was calculated from the ratio $\left(W_{s}-W_{D}\right) / W_{D}$.

3.10. Procedure for Column Utilization (Breakthrough Curve). The column used has a diameter of $2 \mathrm{~cm}$ and a length of 
TABLE 4: Thermal analysis of algae materials: Enteromorpha algae (E), Enteromorpha algae with adsorbed Lead (E-Pb), and Enteromorpha algae modified with sodium silicates (EM).

\begin{tabular}{|c|c|c|c|}
\hline Sample & Peak $\left({ }^{\circ} \mathrm{C}\right)$ (temperature range) & $\begin{array}{c}\text { \% Experimental } \\
\text { mass loss }\end{array}$ & Enthalpy (J/g) \\
\hline \multirow{6}{*}{ (E) } & 84.10 & 12.77 & 238.50 \\
\hline & 174.82 & 3.34 & 8.22 \\
\hline & 215.12 & 33.88 & -17.31 \\
\hline & 231.41 & - & 23.98 \\
\hline & 442.21 & 16.22 & 541.42 \\
\hline & 726.16 & 20.91 & 254.63 \\
\hline \multirow{5}{*}{$(\mathrm{E}-\mathrm{Pb})$} & 73.61 & 17.83 & 234.55 \\
\hline & 169.58 & - & 19.72 \\
\hline & 221.14 & 39.14 & -30.03 \\
\hline & 428.15 & 15.57 & -7.14 \\
\hline & 656.85 & 21.91 & 161.65 \\
\hline \multirow{4}{*}{$(\mathrm{EM})$} & $(25-180)$ & 4.0 & - \\
\hline & $(180.0-750.0)$ & 13.0 & 41.59 \\
\hline & 290.56 & - & - \\
\hline & 756.85 & 2.0 & 13.43 \\
\hline
\end{tabular}

$44 \mathrm{~cm}$. It was packed uniformly with $1.0 \mathrm{~g}$ of green Enteromorpha algae powder (E) or Enteromorpha algae powder after reflux (ER) or modified Enteromorpha algae with sodium silicates (EM). The column dead volume was $30 \mathrm{~mL}$. The lead solution (200 ppm) at $\mathrm{pH} 3.0$ was drained through the column at a constant rate $2.5 \mathrm{~mL} / \mathrm{min}$ in the case of (E) and (ER). The lead solution (1000 ppm) was eluted at a rate of $2.0 \mathrm{~mL} / \mathrm{min}$ in the case of column packed with (EM). Collected aliquots of similar volume were collected from the column and analyzed for lead [37].

\section{Result and Discussion}

4.1. Infrared Spectroscopy. FTIR spectra of Enteromorpha algae (E) show strong stretch at $3395 \mathrm{~cm}^{-1}$ due to $-\mathrm{NH}$ of amino group, strong stretch at $1646.5 \mathrm{~cm}^{-1}$ and a weaker ones at $1436 \mathrm{~cm}^{-1}$ due to carboxylate group, and strong bending vibration at 1105 and $1158 \mathrm{~cm}^{-1}$ due to $\mathrm{C}-\mathrm{O}$ of ether and alcoholic group, respectively [38]. FTIR spectra of Enteromorpha algae with adsorbed lead also show many peaks similar to free algae spectra. However the peak due to $-\mathrm{NH}$ stretch has been shifted to lower wave number $3291 \mathrm{~cm}^{-1}$ indicating involvement of binding of lead to $-\mathrm{NH}$ group. The bands due to carboxylate group show a little shift to higher wave number $\left(1651 \mathrm{~cm}^{-1}\right)$ compared to free algae peak, indicating the involvement of carboxylate and ester groups in the binding with lead.

FTIR of (EM) is similar to that of (E) but with increasing peak strength at $1100 \mathrm{~cm}^{-1}$ and at $3437 \mathrm{~cm}^{-1}$ due to $\mathrm{Si}-\mathrm{O}-\mathrm{Si}$ and $\mathrm{SiO}-\mathrm{H}$ stretching vibrations, while FTIR of (ER) has no noticeable difference from that of $(\mathrm{E})$.

4.2. Thermal Analysis. Thermogravimetry analysis (TGA) and differential scanning calorimetry (DSC) curves were recorded for algae materials, which were heated to $800^{\circ} \mathrm{C}$ under $\mathrm{N}_{2}$, where all relevant weight loss was complete. The results of thermal analysis (\% mass loss at each temperature and associated enthalpy) of free Enteromorpha algae (E) and algae with adsorbed lead $(\mathrm{E}-\mathrm{Pb})$ and modified algae with sodium silicates (EM) are listed in Table 4. The two TGA and dTG curves reveal difference between loss in weight with temperatures for both materials $(\mathrm{E})$ and $(\mathrm{E}-\mathrm{Pb})$, with greatest difference occurring about $220^{\circ} \mathrm{C}$ where free algae show a loss of $33.88 \%$ at $215.12^{\circ} \mathrm{C}$ (exothermic) and $231.41^{\circ} \mathrm{C}$ (endothermic) while algae with biosorbed lead show a loss of $39.14 \%$ at $221.14^{\circ} \mathrm{C}$ (exothermic). The $5.26 \%$ difference in mass loss between the two could be attributed to the adsorbed amount of lead. This peak is shifted to higher temperature $\left(290.56^{\circ} \mathrm{C}\right)$ in the case of (EM) with endothermic peak, indicating chemical binding of algae to sodium silicates. The amount of bonded algae is about $19.0 \%$.

The sharp decrease at $726.16^{\circ} \mathrm{C}(20.91 \%)$ for $(\mathrm{E}), 656.85^{\circ} \mathrm{C}$ (21.91\%) for (E-Pb), and $756.85^{\circ} \mathrm{C}$ for (EM), respectively, is associated with high endothermic heat energy attributed to the conversion of $\mathrm{CaCO}_{3}(\mathrm{~s})$ to $\mathrm{CaO}(\mathrm{s})$ and $\mathrm{CO}_{2}(\mathrm{~g})$. The weight loss occurring before this step $\left(50\right.$ to $600^{\circ} \mathrm{C}$ ) is due to organic materials volatilization and decomposition.

\subsection{Batch Studies}

4.3.1. Effect of Mass of Algae. The effect of mass of algae on metal uptake was studied in batch system for initial lead concentration (300 ppm) and contact time (24h) in water bath at $25^{\circ} \mathrm{C}$. There was a steep increase in $\%$ extraction of lead as the mass of algae increased from $0.05 \mathrm{~g}$ to $0.30 \mathrm{~g}$ (from $53 \%$ to $82 \%)$. For biomass weight greater than $0.30 \mathrm{~g}$ there were no significant increases in the metal uptake. Thus the optimum mass of algae (E) and (ER) was $0.30 \mathrm{~g}$ corresponding to a maximum \% metal uptake for a volume reaction of $25 \mathrm{~mL}$ 


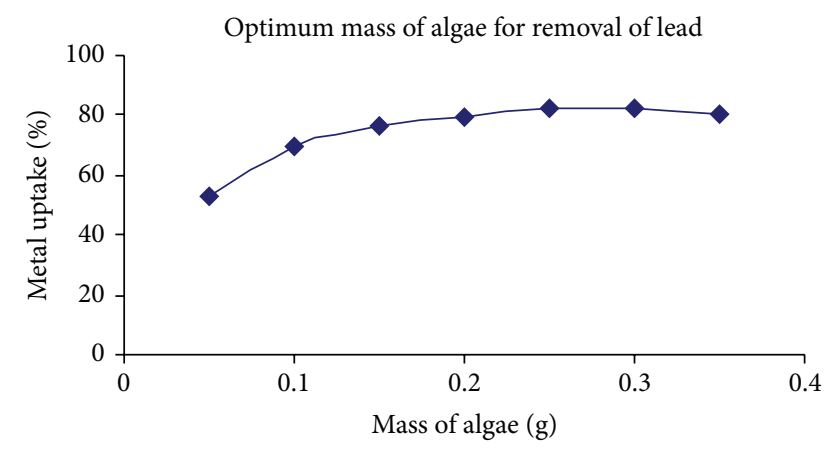

FIGURE 1: Effect of mass of Enteromorpha algae on metal uptake for a $25 \mathrm{~mL}$ lead solution (300 ppm).

lead (300 ppm), Figure 1, while the optimum mass and reaction volume are $0.1 \mathrm{~g}$ and $100 \mathrm{~mL}$ for (EM).

4.3.2. $p H$ Effect. Experiments concerning the effect of $\mathrm{pH}$ on the sorption were carried out within a $\mathrm{pH}$ range that avoids the metal precipitation as hydroxide. The standard lead solution (300 ppm) was prepared in acetate buffer to cover a $\mathrm{pH}$ range 3.0-7.5. The data of metal uptake by $0.30 \mathrm{~g}$ algae in a $25 \mathrm{~mL}$ standard lead solution was studied for different $\mathrm{pH}$ values. It was found that lead shows maximum binding to the biomass at an optimum $\mathrm{pH} 3.0$ with a metal uptake of $86.62 \%$ and capacity of $21.55 \mathrm{mg} / \mathrm{g}$. There is no change in metal uptake for $\mathrm{pH}$ values between 3.6 and 7.5 .

4.3.3. Effect of Lead Concentration. The experimental effect of lead concentration on metal uptake was done in batch system concentrations of $0.3 \mathrm{gm}$ at optimum pH 3.0 (using sodium acetate buffer) for a residence time of $24 \mathrm{hrs}$ and different lead concentrations in the range (10-1000 ppm). There was a sharp increase in adsorption as lead concentration increases from 10 to $150 \mathrm{ppm}$ and reaches a maximum at $200 \mathrm{ppm}$ lead with a \% metal uptake of $95.50 \%$ and a metal uptake capacity $q$ of $15.29 \mathrm{mg} / \mathrm{g}$ algae. For lead solution greater than $200 \mathrm{ppm}$, the algae become saturated and a decrease in \% uptake was noticed. Thus the optimum concentration was found to be 200 ppm.

4.3.4. Effect of Residence Time. Previous work showed that sorption of heavy metal ions by lived algae followed a twostep mechanism where the metal ion was physico/chemically uptaken onto the surface of the algae before being taken up biologically into the cell. The first step, known as a passive transport, took place quite rapidly, that is, within 20-30 min, whilst the second biological step or active transport could take much longer time to complete. In this case, since the algae were dried and biological functions were no longer active, the sorption could only take place on the surface of the cell. Therefore the sorption equilibrium took place quickly within $20 \mathrm{~min}$ and no further sorption was observed thereafter $[39,40]$.

The effect of residence time on metal uptake was studied with $0.30 \mathrm{~g}$ algae in $25 \mathrm{~mL}$ lead solution 200 (ppm) at

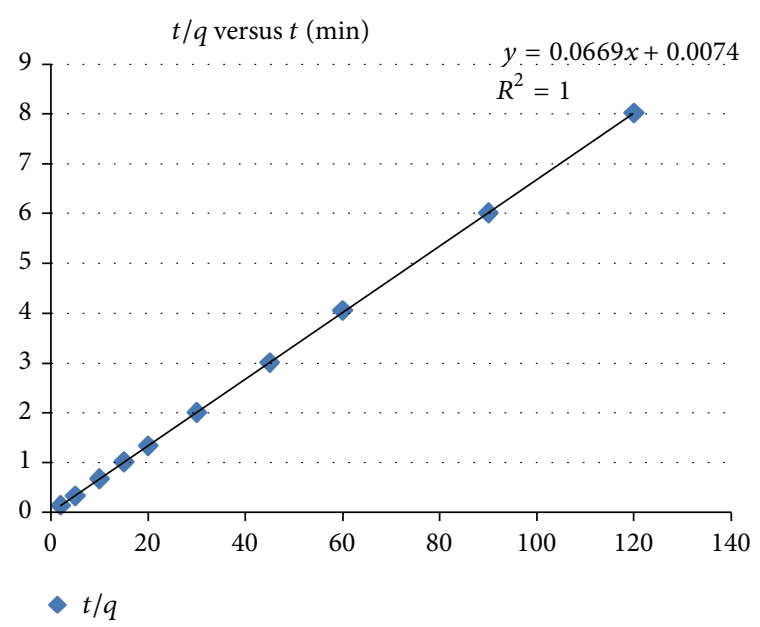

FIgUre 2: Pseudosecond order kinetics for adsorption of lead onto Enteromorpha algae (E) at $25^{\circ} \mathrm{C}$.

optimum pH 3.0 using sodium acetate buffer and variable residence time (2-120 $\mathrm{min})$, in which each flask was periodically shaken at 200 r.p.m for $2 \mathrm{~min}$. This experiment shows that algae have bound most of the metal after $20 \mathrm{~min}$ and that equilibrium was reached after maximum metal uptake $88.94 \%$ (capacity $14.49 \mathrm{mg} / \mathrm{g}$ ). This result is in parallel with those previously obtained with different algae and fungi for heavy metal uptake [37].

The linear equation for pseudosecond order model [41] is as follows:

$$
\frac{t}{q_{t}}=\frac{1}{k_{2}\left(q_{e}\right)^{2}}+\frac{t}{q_{e}}
$$

where $q_{e}$ and $q_{t}$ in $\mathrm{mg} / \mathrm{g}$ are the amount of lead adsorbed at equilibrium and at time $t$, respectively. $k_{2}\left(\mathrm{~g} \cdot \mathrm{mg}^{-1} \cdot \mathrm{min}^{-1}\right)$ is the rate constant of pseudosecond order adsorption. The plot of $t / q_{t}$ versus $t$ (min) gave a linear relationship from which $q_{e}$ was determined from the slope and $k_{2}$ from the intercept of the plot, Figure 2. The values of $k_{2}, q_{e}$, and $R^{2}$ are $0.605,14.95$, and 1.0, respectively. $R^{2}=1.0$ for the plot clearly indicates that adsorption kinetics is best described as pseudosecond order.

4.3.5. Swelling Behavior. The volume of swollen particles increased during the first 20 minutes and then it remained constant during 2 hours. The values of DI, Q, and $V_{\text {AS }}$ of the biomass particles are presented in Table 5. The values for algae modified with silicates (EM) and algae after reflux (ER) indicate an improvement of stability and mechanical properties of the biomass and better flow rate [27].

4.3.6. Adsorption Isotherm Calculations. Adsorption is usually modeled by isotherms which relate the relative concentrations of solute adsorbed to the solid $\left(Q_{e}\right)$ and in solution $\left(C_{e}\right)$. The equilibrium data were analyzed using most commonly used nonlinear isotherms equations: Langmuir, Freundlich, Redlich-Peterson, Temkin, Elovich, and Dubinin-Radushkevich models, Table 1, Figure 3 [31-33]. 
TABLE 5: Swelling characteristics of different algae biomass.

\begin{tabular}{|c|c|c|c|c|c|c|c|}
\hline Type of biomass & $\begin{array}{c}\text { Particle size } \\
\text { (mesh) }\end{array}$ & $\begin{array}{r}W_{D} \\
(\mathrm{~g}) \\
\end{array}$ & $\begin{array}{l}W_{s} \\
(\mathrm{~g})\end{array}$ & Q & $\begin{array}{c}V_{s} \\
\mathrm{~cm}^{3}\end{array}$ & $\begin{array}{c}\mathrm{DI} \\
\mathrm{cm}^{3} / \mathrm{g}\end{array}$ & $V_{\mathrm{AS}}$ \\
\hline Enteromorpha algae (E) & 0.5 & 1.442 & 10.41 & 7.219 & 10 & 6.934 & 6.219 \\
\hline $\begin{array}{l}\text { Enteromorpha algae after reflux } \\
\text { (ER) }\end{array}$ & 0.5 & 1.442 & 6.876 & 4.775 & 7 & 4.166 & 3.775 \\
\hline $\begin{array}{l}\text { Enteromorpha algae modified } \\
\text { with silicates (EM) }\end{array}$ & 0.5 & 4.320 & 11.54 & 3.687 & 10.5 & 2.430 & 1.671 \\
\hline Swedish wood sawdust (SWS) & 0.5 & 1.442 & 8.92 & 6.185 & 10 & 6.935 & 5.185 \\
\hline
\end{tabular}

TABLE 6: Results of nonlinear approach of Langmuir, Freundlich, Temkin, Elovich, Redlich-Peterson, and Dubinin-Radushkevich isotherm constants for the adsorption of lead at $25^{\circ} \mathrm{C}$ onto (a) raw Enteromorpha (E); (b) Enteromorpha modified with sodium silicates (EM).

(a)

\begin{tabular}{|c|c|c|c|c|c|c|c|c|}
\hline \multicolumn{9}{|c|}{ Sorbent (E) } \\
\hline \multicolumn{3}{|c|}{ Langmuir } & \multicolumn{3}{|c|}{ Freundlich } & \multicolumn{3}{|c|}{ Temkin } \\
\hline$Q^{0}$ calc $(\mathrm{mg} / \mathrm{g})$ & $K_{L}(\mathrm{~L} / \mathrm{mg})$ & $R^{2}$ & $K_{F}(\mathrm{~L} / \mathrm{g})$ & $n$ & $R^{2}$ & $B_{T}(\mathrm{~J} / \mathrm{mol})$ & $K_{T}(\mathrm{~L} / \mathrm{mg})$ & $R^{2}$ \\
\hline 83.82 & 0.0105 & 0.879 & 0.3411 & 0.8576 & 0.9593 & 14.342 & 0.143 & 0.8562 \\
\hline$\chi^{2}$ & SSE & & $\chi^{2}$ & SSE & & $\chi^{2}$ & SSE & \\
\hline 20.66 & 165.29 & & 6.970 & 55.76 & & 24.651 & 197.21 & \\
\hline \multicolumn{3}{|c|}{ Elovich } & \multicolumn{3}{|c|}{ Redlich-Peterson } & \multicolumn{3}{|c|}{ Dubinin-Radushkevich } \\
\hline$Q_{E}(\mathrm{mg} / \mathrm{g})$ & $K_{E}(\mathrm{~L} / \mathrm{mg})$ & $R^{2}$ & $A_{\mathrm{RP}}(\mathrm{L} / \mathrm{mg})^{\beta}$ & $\beta_{\mathrm{RP}}$ & $K_{\mathrm{RP}}(\mathrm{L} / \mathrm{g})$ & $Q_{m}(\mathrm{mg} / \mathrm{g})$ & $\beta\left(\mathrm{mol}^{2} / \mathrm{J}^{2}\right)$ & $E(\mathrm{~J} / \mathrm{mol})$ \\
\hline 42.8513 & -0.00786 & 0.52311 & 1.3644 & 0.5525 & 0.1754 & 37.92 & $-8 \times 10^{-5}$ & 79.06 \\
\hline$\chi^{2}$ & SSE & & $R^{2}$ & $\chi^{2}$ & SSE & $R^{2}$ & $\chi^{2}$ & SSE \\
\hline 0.02838 & 0.2270 & & 0.8160 & 36.16 & 253.14 & 0.9532 & 8.0182 & 64.15 \\
\hline
\end{tabular}

(b)

\begin{tabular}{|c|c|c|c|c|c|c|c|c|}
\hline \multicolumn{9}{|c|}{ Sorbent (EM) } \\
\hline \multicolumn{3}{|c|}{ Langmuir } & \multicolumn{3}{|c|}{ Freundlich } & \multicolumn{3}{|c|}{ Temkin } \\
\hline$Q^{0}$ calc $(\mathrm{mg} / \mathrm{g})$ & $K_{L}(\mathrm{~L} / \mathrm{mg})$ & $R^{2}$ & $K_{F}(\mathrm{~L} / \mathrm{mg})$ & $n$ & $R^{2}$ & $B_{T}(\mathrm{~J} / \mathrm{mol})$ & $K_{T}(\mathrm{~L} / \mathrm{mg})$ & $R^{2}$ \\
\hline 1433.46 & 0.00157 & 0.9872 & 6.7298 & 1.3555 & 0.9925 & 186.746 & 0.0373 & 0.9260 \\
\hline$\chi^{2}$ & SSE & & $\chi^{2}$ & SSE & & $\chi^{2}$ & SSE & \\
\hline 415.336 & 3322.7 & & 241.09 & 1928.74 & & 2392 & 19136 & \\
\hline \multicolumn{3}{|c|}{ Elovich } & \multicolumn{3}{|c|}{ Redlich-Peterson } & \multicolumn{3}{|c|}{ Dubinin-Radushkevich } \\
\hline$Q_{E}(\mathrm{mg} / \mathrm{g})$ & $K_{E}(\mathrm{~L} / \mathrm{mg})$ & $R^{2}$ & $A_{\mathrm{RP}}(\mathrm{L} / \mathrm{mg})^{\beta}$ & $\beta_{\mathrm{RP}}$ & $K_{\mathrm{RP}}(\mathrm{L} / \mathrm{g})$ & $Q_{m}(\mathrm{mg} / \mathrm{L})$ & $\beta\left(\mathrm{mol}^{2} / \mathrm{kj}^{2}\right)$ & $E(\mathrm{~J} / \mathrm{mol})$ \\
\hline 754.41 & 0.00366 & 0.7515 & 10.4550 & 0.313 & 0.9915 & 557.44 & -0.00244 & 14.32 \\
\hline$\chi^{2}$ & SSE & & $R^{2}$ & $\chi^{2}$ & SSE & $\chi^{2}$ & SSE & $R^{2}$ \\
\hline 0.0607 & 0.4853 & & 0.9924 & 282.1 & 1974.5 & 5440.24 & 43522 & 0.8317 \\
\hline
\end{tabular}

The data is well fitted with Langmuir model indicating the presence of chemical monolayer adsorption onto a surface with a finite number of similar active sites. The calculated maximum sorbate uptake $Q^{0}(\mathrm{mg} / \mathrm{g})$ is 83.82 for nonmodified algae (E) and $1433.46 \mathrm{mg} / \mathrm{g}$ for algae modified with sodium silicates (EM). The $K_{L}$ and $R_{L}$ values are also calculated where $R_{L}=1 /\left(1+K_{L} C_{0}\right)$ and $K_{L}$ is a coefficient related to the affinity between the sorbent and sorbate. $C_{0}$ is the maximum initial concentration. The $R_{L}$ value implies that adsorption to be unfavorable for $\left(R_{L}>1\right)$, linear for $\left(R_{L}=1\right)$, and favorable for $\left(O<R_{L}<1\right)$, or irreversible $\left(R_{L}=0\right)$. Adsorption of lead is favorable since the obtained value of $R_{L}$ for the materials (E) is (0.0872) and for (EM) is (0.389), Table 6. The ability of Freundlich model was examined. It is the best suited model in our study indicating that sorption occurs onto a heterogeneous surface. It was also reported that Freundlich model was applicable in adsorption studies of lead with Enteromorpha algae [37]. It is of importance to realize that the values of $1 / n$ greater than unity in the case of $(\mathrm{E})$ algae indicate formation of multilayer of metal on the surface of biomass, Table 6 .

Redlich-Peterson model is also suitable model, where $A_{\mathrm{RP}}$, $K_{\mathrm{RP}}$, and $\beta$ are parameters to be estimated, Table 1 . The obtained $\beta$ values lie in the middle between 0 and 1 indicating that adsorption includes both Freundlich and Langmuir features, Table 6. Temkin model explains sorbent/sorbate interactions in relation to heat of adsorption, where $B_{T}$ is a factor related to the heat of adsorption and $K_{T}$ is Temkin equilibrium constant (L/mg). The $B_{T}$ for (EM) $186.75 \mathrm{~J} / \mathrm{mol}$ is much greater than $14.34 \mathrm{~J} / \mathrm{mol}$ for (E), Tables 1 and 6 . 


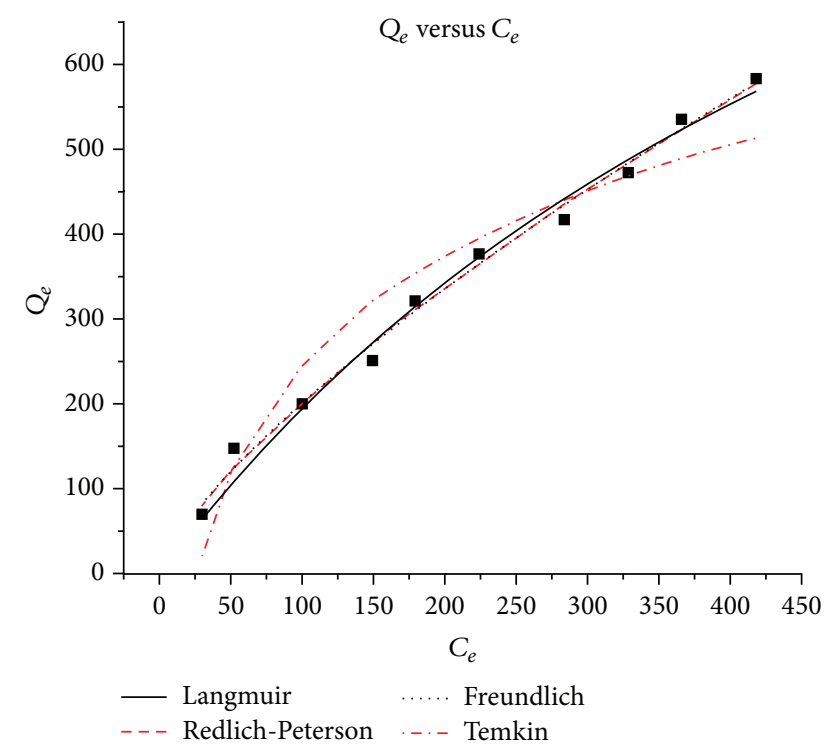

FIGURE 3: The curves of the four nonlinear isotherm models with the experimental data at $t=25^{\circ} \mathrm{C}$, for adsorption of lead onto Enteromorpha modified with sodium silicates (EM).

Elovich model deals with multilayer adsorption, based on a kinetic principle that adsorption site increase exponentially with adsorption, where $K_{E}$ is Elovich equilibrium constant and $Q_{E}$ is Elovich maximum adsorption capacity. The low $R^{2}$ value indicates than Elovich model is not applicable to lead adsorption onto (E) and (EM) in Tables 1 and 6.

Dubinin-Radushkevich isotherm, where $Q_{m}$ is the maximum amount of ions sorbed onto algae $(\mathrm{mg} / \mathrm{g}), \beta\left(\mathrm{mol}^{2} / \mathrm{kJ}^{2}\right)$ is a constant related to the sorption energy $E=1 / \sqrt{-2 \beta}$ in $\mathrm{kJ} / \mathrm{mol}$, Table 1 . The obtained values of $E 14.32 \mathrm{~kJ} / \mathrm{mol}$ for modified algae (EM) and $79.06 \mathrm{~kJ} / \mathrm{mol}$ for nonmodified algae (E) are greater than $8 \mathrm{~kJ} / \mathrm{mol}$, indicating that the adsorption process is chemical in nature, Table 6 .

4.3.7. Comparative with Literatures. However, the results obtained for metal uptake $(q)$ of lead cations using dead algae E. intestinalis (E) in agitation experiments at optimum conditions show a medium uptake of E. intestinalis for these cations in comparison to the other published data, Table 7 [43-47, 49-52]. However, the highest adsorption capacity $1433 \mathrm{mg} / \mathrm{g}$ was obtained for Enteromorpha algae modified with sodium silicates (EM) indicating the presence of strong electrostatic force of attraction between lead ions and binding-sites on the surface of the silicates-algae modified material. This indicates that silicates support greatly improves the adsorption capacity compared to nonmodified algae.

4.4. Column Studies. The batch experiments have demonstrated the ability of green algae Enteromorpha to bind lead ions from solution. A practical approach to decontaminate metal-polluted water with the biomass would be to pass the contaminated water through a column contain the biomass. This experiment was performed using different biomass in which the biomass was packed in the column by rewetting it in deionized water.

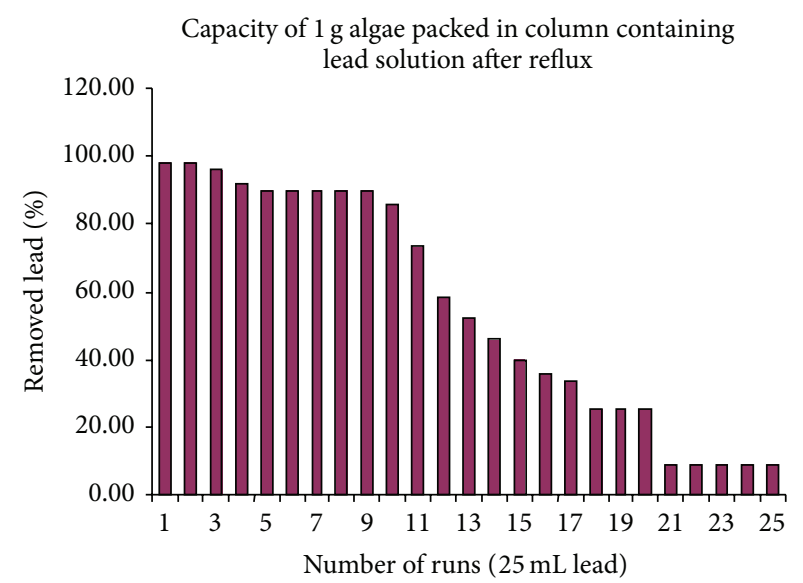

Figure 4: Saturation of the column after passage of 25 aliquots of $25 \mathrm{~mL}$ lead $(200 \mathrm{ppm})$ for a column filled with $1 \mathrm{~g}$ Enteromorpha algae residue after reflux (ER).

4.4.1. Column Capacity. The breakthrough curve of lead was determined using column packed uniformly with $1.0 \mathrm{~g}$ of Enteromorpha algae materials (E), (ER), or (EM). Aliquots were collected from the column and analyzed for lead till reaching saturation, Figure 4 . The column capacity $q_{e}$ was calculated from the area $A$ under the breakthrough curve (Figure 5) according to the equations presented in Table 8.

(i) The experiment using column filled with (E) showed that $67.4 \mathrm{mg} / \mathrm{g}$ of lead was removed after passage of $525 \mathrm{~mL}$ solutions of lead (200 ppm) and that the percent removal is $64.2 \%$. This result is in parallel with those recently obtained with different microalgae Chlamydomonas reinhardtii for heavy metal uptake [45].

(ii) In the case of column filled with (ER), saturation occurs after passage of $625 \mathrm{~mL}$ of lead (200 ppm). The column capacity and percent removal are $66.3 \mathrm{mg} / \mathrm{g}$ and $53.04 \%$, respectively.

(iii) Column studies using sodium silicates modified algae (EM) indicate higher adsorption capacity and \% removal $(230.20 \mathrm{mg} / \mathrm{g}$ and $60.6 \%$, resp.). Saturation occurred after passage of $380 \mathrm{~mL}$ of lead (1000 ppm).

4.4.2. Column Models. Three kinetic coulmn models (Thomas, Yoon-nelson, and Yan and Clark) (Table 2) were used to analyze column performance using the data for the adsorption of lead (1000 ppm) with $1 \mathrm{gm}$ (EM) materials.

Thomas model assumes negligible axial dispersion in the column adsorption since the rate driving force obeys the second order reversible reaction kinetics. $K_{\mathrm{Th}}(\mathrm{mL} / \mathrm{mg} \cdot \mathrm{min})$ is Thomas rate constant, $q_{T}(\mathrm{mg} / \mathrm{g})$ is the equilibrium adsorption capacity, $m(\mathrm{~g})$ is the amount of adsorbent in the column, $Q(\mathrm{~mL} / \mathrm{min})$ is the volumetric flow rate, and $C_{o}(\mathrm{mg} / \mathrm{L})$ is the initial concentration of the adsorbate in the feed solution [48].

Yoon-Nelson developed a model based on the assumption that the rate of decrease in the probability of adsorption for 
TABLE 7: Lead uptake: optimum results obtained from batch experiments, comparison with literature.

\begin{tabular}{|c|c|c|c|c|}
\hline Name of algae-color & $\mathrm{pH}$ & $\begin{array}{l}\text { Contact time } \\
(\mathrm{min})\end{array}$ & $\begin{array}{c}\text { Metal uptake } \\
(q) \mathrm{mg} / \mathrm{g}\end{array}$ & Reference \\
\hline E. intestinalis (E)-green & 3.0 & $5-20$ & 83.82 & Present work \\
\hline E. intestinalis modified with sodium silicates (EM)-green & 7.0 & 60 & 1433.46 & Present work \\
\hline Caulerpa lentillifera-green & 5.0 & $10-20$ & 28.71 & {$[43]$} \\
\hline Cystoseira baccata-brown & 4.5 & - & 186 & {$[44]$} \\
\hline Chlamydomonas reinhardtii-green & 5.0 & 60 & 96.30 & {$[45]$} \\
\hline Sargassum sp.-brown & 5.0 & 60 & 183.37 & {$[46]$} \\
\hline Ulva lactuca-green & $4-5$ & $5-30$ & 126.5 & {$[47]$} \\
\hline Enteromorpha spp. (living)_-green & - & $0-5$ & 20.72 & {$[28]$} \\
\hline Anabaena sphaerica-blue green & 3.0 & 90 & 121.95 & {$[52]$} \\
\hline Mixture of Ulva lactuca, Jania Rubens, and Sargassum (green, red, and brown) & 4.0 & 120 & 281.80 & {$[36]$} \\
\hline Ecklonia radiata-brown & 5.0 & 10 & 282 & {$[49]$} \\
\hline Codiumtaylori-green & 3.5 & - & 130.00 & {$[50]$} \\
\hline Sargassum natans-brown & 3.5 & - & 220.00 & [51] \\
\hline
\end{tabular}

TABLE 8: Column adsorption capacity and parameters calculation of a column loaded with (a) $1 \mathrm{gm}$ of (E), (b) 1 gm of (ER), eluted with MG $200 \mathrm{ppm}$ at a flow rate $Q$ of $2.5 \mathrm{~mL} / \mathrm{min}$, and (c) with $1 \mathrm{gm}(\mathrm{EM})$ eluted with $\mathrm{MG} 1000 \mathrm{ppm}$ at $Q=2.0 \mathrm{~mL} / \mathrm{min}$.

\begin{tabular}{|c|c|c|c|c|c|c|}
\hline Parameter & $A=$ & $q_{\text {total }}=$ & $m_{\text {total }}=$ & $\%$ total removal $=$ & $q_{e}=$ & $C_{e}=$ \\
\hline Equation & $\int_{t=o}^{t=t_{\text {total }}} C_{\text {ads }} d t$ & $\frac{Q A}{1000}$ & $\frac{C_{o} Q t_{\text {total }}}{1000}$ & $\frac{q_{\text {total }}}{m_{\text {total }}} \times 100$ & $\frac{q_{\text {tot }}}{m}$ & $C_{o}-\frac{A}{t_{\text {total }}}$ \\
\hline Unit & $\mathrm{mg} \cdot \mathrm{min} / \mathrm{L}$ & $\mathrm{mg}$ & $\mathrm{mg}$ & $\%$ & $\mathrm{mg} / \mathrm{g}$ & $\mathrm{mg} / \mathrm{L}$ \\
\hline (a) (E) & 26948 & 67.37 & 105 & 64.16 & 67.37 & 71.68 \\
\hline (b) (ER) & 26520 & 66.30 & 125 & 53.04 & 66.30 & 93.92 \\
\hline (c) $(\mathrm{EM})$ & 115095 & 230.20 & 380 & 60.58 & 230.19 & 394.24 \\
\hline
\end{tabular}

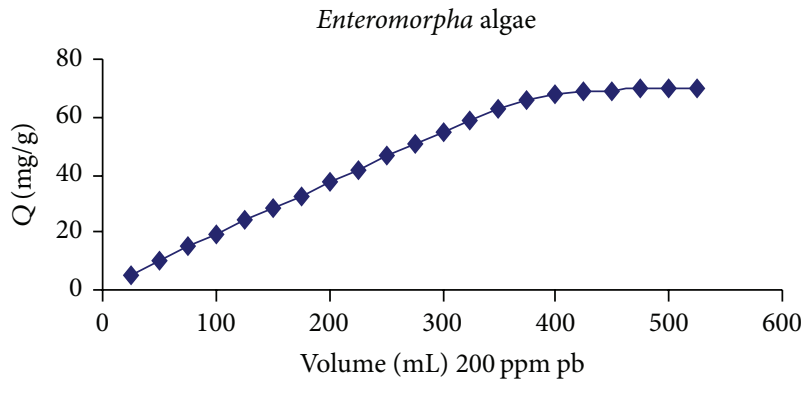

FIGURE 5: Breakthrough curve: capacity of 1 gram of Enteromorpha algae (E) at $\mathrm{pH} 3$ and flow rate $2.5 \mathrm{~mL} / \mathrm{min}$ with $200 \mathrm{ppm}$ lead solution (particle size 0.5 mesh).

each adsorbate molecule is proportional to the probability of adsorbate adsorption and the probability of adsorbate breakthrough on the adsorbent. $K_{\mathrm{YN}}\left(\mathrm{min}^{-1}\right)$ is the rate constant and $\tau_{\mathrm{YN}}(\mathrm{min})$ is the time required for $50 \%$ adsorbate breakthrough [53].

Yan et al. model is described in Table 2, where $K_{Y}$ $(\mathrm{L} / \mathrm{min} \cdot \mathrm{mg})$ is the kinetic rate constant for Yan et al. model and $q_{Y}(\mathrm{mg} / \mathrm{g})$ is the maximum adsorption capacity of adsorbent estimated by Yan model [42].

Thomas, Yoon-Nelson, and Yan and Clark models were applied using linear and nonlinear regression statistical techniques according to the equations listed in Table 2 . The values of the maximum capacity $q$, the rate constant $K$, and error functions for each model are presented in Table 9. The nonlinear methods having higher $R^{2}$ values would be more appropriate techniques in predicting the adsorption column models, for nonlinear methods.

Comparing the values of $\chi^{2}$, SSE, and $R^{2}$, we find that Thomas and Yoon-Nelson models describe better the adsorption behavior than Yan model for column packed with (E) and (ER). However, Yan model was found the best for column packed with (EM). The predicted capacity value is $q_{T}=q_{\mathrm{YN}}=76.2 \mathrm{mg} / \mathrm{g}$ for column (E) and $=71.1 \mathrm{mg} / \mathrm{g}$ in the case of column (ER), while the capacity $q_{Y}$ is equal to 982.5 for column (EM). Again algae anchoring onto silicates improved the performance capacity of column more than 10 times compared to nonmodified algae materials. Application of Yoon-Nelson model indicated that $\tau$ the half-life of adsorbate breakthrough is equal to $152.35 \mathrm{~min}$ and $142.10 \mathrm{~min}$ for column (E) and (ER), respectively using nonlinear approach, Table 9.

\section{Conclusion}

(i) The amount of lead uptake increased steeply by increasing the weight of Enteromorpha intestinalis algae and reached equilibrium state after 20 minutes in batch experiment with $g$ at $25^{\circ} \mathrm{C}$. The algae show also high adsorption of lead at optimum conditions 
TABLE 9: Statistical evaluation of parameters of a column loaded with $1 \mathrm{gm}$ (EM) and eluted with $1000 \mathrm{ppm}$ lead using linear and nonlinear fit of breakthrough data to Thomas, Yoon-nelson, and Yan and Clark kinetic models.

\begin{tabular}{|c|c|c|c|c|c|c|c|c|c|c|}
\hline & Adsorbent & & inear approach & & & & Nonlinear at & proach & & \\
\hline \multirow{4}{*}{$\begin{array}{l}\text { Thomas } \\
\text { model }\end{array}$} & & $\begin{array}{c}K_{\mathrm{Th}} \\
\mathrm{mL} \cdot(\mathrm{mg} \cdot \mathrm{min})^{-1}\end{array}$ & $\begin{array}{c}q_{T} \\
\left(\mathrm{mg} \cdot \mathrm{g}^{-1}\right)\end{array}$ & $R^{2}$ & SD & $\begin{array}{c}K_{\mathrm{Th}} \\
\mathrm{mL} \cdot(\mathrm{mg} \cdot \mathrm{min})^{-1}\end{array}$ & $\begin{array}{c}q_{T} \\
\left(\mathrm{mg}^{-1} \mathrm{~g}^{-1}\right)\end{array}$ & $R^{2}$ & SSE & $x^{2}$ \\
\hline & (E) & $1.72 \times 10^{-4}$ & 69.25 & 0.8305 & 0.8988 & $3.1 \times 10^{-4}$ & 76.18 & 0.9720 & 0.07145 & $3.8 \times 10^{-3}$ \\
\hline & (ER) & $1.32 \times 10^{-4}$ & 72.14 & 0.9677 & 0.3529 & $1.4 \times 10^{-4}$ & 71.08 & 0.9827 & 0.0496 & 0.0022 \\
\hline & $(\mathrm{EM})$ & $7.15 \times 10^{-6}$ & 375.9 & 0.6994 & 0.2715 & $6.0 \times 10^{-6}$ & 396.78 & 0.7422 & 0.0397 & 0.0023 \\
\hline \multirow{4}{*}{$\begin{array}{l}\text { Yoon-Nelson } \\
\text { model }\end{array}$} & & $K_{\mathrm{YN}}\left(\min ^{-1}\right)$ & $\begin{array}{c}\tau_{\mathrm{YN}}(\min ) \\
q_{\mathrm{YN}}\left(\mathrm{mg}^{-1}\right)\end{array}$ & $R^{2}$ & SD & $K_{\mathrm{YN}}\left(\min ^{-1}\right)$ & $\begin{array}{c}\tau_{\mathrm{YN}}(\min ) \\
q_{\mathrm{YN}}\left(\mathrm{mg}^{-1}\right)\end{array}$ & $R^{2}$ & SSE & $\chi^{2}$ \\
\hline & (E) & 0.0344 & $\begin{array}{r}138.50 \\
69.26\end{array}$ & 0.8305 & 0.8988 & 0.0615 & $\begin{array}{c}152.35 \\
76.18\end{array}$ & 0.9720 & 0.07145 & 0.0038 \\
\hline & (ER) & 0.0264 & $\begin{array}{c}144.18 \\
72.10\end{array}$ & 0.9651 & 0.3529 & 0.0280 & $\begin{array}{c}142.10 \\
71.05\end{array}$ & 0.9819 & 0.04839 & 0.0022 \\
\hline & $(\mathrm{EM})$ & 0.0072 & $\begin{array}{l}187.96 \\
375.92\end{array}$ & 0.6994 & 0.2715 & 0.0061 & $\begin{array}{l}198.40 \\
396.80\end{array}$ & 0.7422 & 0.03969 & 0.0023 \\
\hline \multirow{4}{*}{ Yan's model } & & $\begin{array}{c}K_{Y} \\
\mathrm{~L} \cdot(\mathrm{mg} \cdot \min )^{-1}\end{array}$ & $\begin{array}{c}q_{Y} \\
\left(\mathrm{mg} \cdot \mathrm{g}^{-1}\right)\end{array}$ & $R^{2}$ & $\chi^{2}$ & $\begin{array}{c}K_{Y} \\
\mathrm{~L} \cdot(\mathrm{mg} \cdot \min )^{-1}\end{array}$ & $\begin{array}{c}q_{Y} \\
\left(\mathrm{mg} \cdot \mathrm{g}^{-1}\right)\end{array}$ & $R^{2}$ & SSE & $\chi^{2}$ \\
\hline & (E) & $4.0 \times 10^{-5}$ & 21.83 & 0.6412 & 1.709 & $1.2 \times 10^{-4}$ & 7.58 & 0.9658 & 0.0874 & 0.0046 \\
\hline & (ER) & $3.3 \times 10^{-5}$ & 23.73 & 0.8525 & 0.0526 & $5.0 \times 10^{-5}$ & 17.16 & 0.9818 & 0.0484 & 0.0022 \\
\hline & $(\mathrm{EM})$ & $1.5 \times 10^{-6}$ & 817.34 & 0.9365 & 0.0156 & $1.0 \times 10^{-6}$ & 982.46 & 0.9387 & 0.0094 & $5.5 \times 10^{-4}$ \\
\hline
\end{tabular}

adsorbent $(0.3 \mathrm{~g}), \mathrm{pH}(3.0)$, and lead concentration $(200 \mathrm{ppm})$ and followed Freundlich model adsorption isotherm. The Langmuir adsorption capacity of lead was $83.8 \mathrm{mg} / \mathrm{g}$ using nonmodified algae (E) and $1433.5 \mathrm{mg} / \mathrm{g}$ using algae modified with silicates (EM). Comparative study of thermal analysis and FTIR of algae materials clearly proves the presence of adsorbed lead in the algae materials.

(ii) Breakthrough area method indicated that $64.2 \%$ and $53.0 \%$ of lead can be removed from 200 ppm eluting solution using column filled with (E) and algae after reflux (ER), respectively, while, for column filled with sodium silicates modified algae (EM), the \% removal was $60.6 \%$ of lead from 1000 ppm. Thomas and YoonNelson models describe better the adsorption behavior than Yan model for column packed with (E) and (ER). The predicted capacity value was $76.2 \mathrm{mg} / \mathrm{g}$ for column (E) and $71.1 \mathrm{mg} / \mathrm{g}$ in the case of column (ER). However, Yan model was the best for column packed with (EM), with a capacity $982.5 \mathrm{mg} / \mathrm{g}$, indicating that sodium silicates modification of algae improved the performance capacity of column. Moreover, (ER) and (EM) show less swelling and better flow rate control than $(\mathrm{E})$.

(iii) The calculation of various error functions proved to be valuable for predicting the best adsorption isotherms, kinetics, and column models. The nonlinear methods would be more appropriate techniques in predicting the best adsorption models.

\section{Conflict of Interests}

The authors declare that there is no conflict of interests regarding the publication of this paper.

\section{References}

[1] J. Dojlido and G. A. Best, Chemistry of Water and Water Pollution, Ellis Horwood, New York, NY, USA, 1993.

[2] A. Stafiej and K. Pyrzynska, "Adsorption of heavy metal ions with carbon nanotubes," Separation and Purification Technology, vol. 58, no. 1, pp. 49-52, 2008.

[3] R. H. Crist, K. Oberholser, J. McGarrity, D. R. Crist, J. K. Johnson, and J. M. Brittsan, "Interaction of metals and protons with algae. 3. Marine algae, with emphasis on lead and aluminum," Environmental Science and Technology, vol. 26, no. 3, pp. 496502, 1992.

[4] B. Volesky and I. Prasetyo, "Cadmium removal in a biosorption column," Biotechnology and Bioengineering, vol. 43, no. 11, pp. 1010-1015, 1994.

[5] J. R. Boulding, EPA Environmental Engineering Sourcebook, Ann Arbor Press, 1996.

[6] R. H. Christ, J. R. Martin, and D. R. Christ, "Ionic mechanisms for heavy metal removal as sulphides and hydroxides," in Mineral Bioprocessing, R. W. Smith and M. Misera, Eds., pp. 275-287, The Mineral, Metals \& Materials Society, Warrendable, $\mathrm{Pa}, \mathrm{USA}, 1991$.

[7] R. Ofer, A. Yerachmiel, and Y. Shmuel, "Marine macroalgae as biosorbents for cadmium and nickel in water," Water Environment Research, vol. 75, no. 3, pp. 246-253, 2003.

[8] N. Kuyucak and B. Volesky, "Biosorbents for recovery of metals from industrial solutions," Biotechnology Letters, vol. 10, no. 2, pp. 137-142, 1988.

[9] M. T. K. Tsui and W.-X. Wang, "Temperature influences on the accumulation and elimination of mercury in a freshwater cladoceran, Daphnia magna," Aquatic Toxicology, vol. 70, no. 3, pp. 245-256, 2004.

[10] G. Lozano, A. Hardisson, A. J. Gutiérez, and M. A. Lafuente, "Lead and cadmium levels in coastal benthic algae (seaweeds) of Tenerife, Canary Islands," Environment International, vol. 28, no. 7, pp. 627-631, 2003. 
[11] X. Sort and J. M. Alcañiz, "Effects of sewage sludge amendment on soil aggregation," Land Degradation \& Development, vol. 10, no. 1, pp. 3-12, 1999.

[12] M. Hanbali, H. Holail, and H. Hammud, "Remediation of lead by pretreated red algae: adsorption isotherm, kinetic, column modeling and simulation studies," Green Chemistry Letters and Reviews, vol. 7, no. 4, pp. 342-358, 2014.

[13] I. Sastre, M. A. Vicente, and M. C. Lobo, "Influence of the application of sewage sludges on soil microbial activity," Bioresource Technology, vol. 57, no. 1, pp. 19-23, 1996.

[14] ISSS Working Group RB, World Reference Base for Soil Resources: Atlas, ISRIC-FAO-ISSS Acco, Leuven, Belgium, 1998.

[15] USEPA, "Method 3051a: Microwave assisted acid dissolution of sediments, Sludges, soils, and oils," 2nd ed U.S. Gov. Print. Office, Washington, DC, USA, 1997.

[16] M. Schnitzer and S. U. Khan, Soil Organic Matter, Elsevier, Amsterdam, The Netherlands, 1978.

[17] G. Gascó, M. J. Martínez-Iñigo, and M. C. Lobo, "Soil organic matter transformation after a sewage sludgeapplication," Electronic Journal of Environmental, Agricultural and Food Chemistry, vol. 3, no. 4, pp. 716-722, 2004.

[18] T. C. Tan, C. K. Chia, and C. K. Teo, "Uptake of metal ions by chemically treated human hair," Water Research, vol. 19, no. 2, pp. 157-162, 1985.

[19] B. Coupal and J. M. Lalancette, "The treatment of waste waters with peat moss," Water Research, vol. 10, no. 12, pp. 1071-1076, 1976.

[20] S. K. Srivastava, R. Tyagi, and N. Pant, "Adsorption of heavy metal ions on carbonaceous material developed from the waste slurry generated in local fertilizer plants," Water Research, vol. 23, no. 9, pp. 1161-1165, 1989.

[21] A. G. Rowley, F. M. Husband, and A. B. Cunningham, "Mechanisms of metal adsorption from aqueous solutions by waste tyre rubber," Water Research, vol. 18, no. 8, pp. 981-984, 1984.

[22] D. K. Singh, D. P. Tiwari, and D. W. Saksena, "Removal of Pb from aqueous Solution by chemically treated used tea leaves," Water Research, vol. 3, pp. 169-177, 1993.

[23] P. Donghee, Chromium removal by biosorption using Ecklonia seaweed Biomass [M.S. thesis], POSTECH, Gyeongsangbuk-do, Republic of Korea, 2002.

[24] Y. S. Yun, D. Park, J. M. Park, and B. Volesky, "Biosorption of trivalent chromium on the brown seaweed biomass," Environmental Science and Technology, vol. 35, no. 21, pp. 4353-4358, 2001.

[25] N. Kuyucak and B. Volesky, in Biosorption of Heavy Metals, B. Volesky, Ed., pp. 173-198, CRC Press, Boca Raton, Fla, USA, 1990.

[26] H. A. Waldern, Stofen Sub-Clinic Lead Poisoning, Academic Press, New York, NY, USA, 1974.

[27] Z. R. Holan, B. Volesky, and I. Prasetyo, "Biosorption of cadmium by biomass of marine algae," Biotechnology and Bioengineering, vol. 41, no. 8, pp. 819-825, 1993.

[28] I. Tüzün, G. Bayramoğlu, E. Yalçın, G. Başaran, G. Çelik, and M. Y. Arıca, "Equilibrium and kinetic studies on biosorption of $\mathrm{Hg}(\mathrm{II}), \mathrm{Cd}(\mathrm{II})$ and $\mathrm{Pb}(\mathrm{II})$ ions onto microalgae Chlamydomonas reinhardtii," Journal of Environmental Management, vol. 77, no. 2, pp. 85-92, 2005.

[29] M. Spinti, H. N. Zhuang, and E. M. Trujillo, "Evaluation of immobilized biomass beads for removing heavy metals from wastewaters," Water Environment Research, vol. 67, no. 6, pp. 943-952, 1995.
[30] R. S. Laxman and S. More, "Reduction of hexavalent chromium by Streptomyces griseus," Minerals Engineering, vol. 15, no. 11, pp. 831-837, 2002.

[31] H. H. Hammud, L. Fayoumi, H. Holail, and M. E. El-Sayed, "Biosorption studies of methylene blue by mediterranean algae carolina and its chemically modified forms. Linear and nonlinear models' prediction based on statistical error calculation," International Journal of Chemistry, vol. 3, no. 4, pp. 147-163, 2011.

[32] H. H. Hammud, M. Chahine, B. El Hamaoui, and Y. Hanifehpour, "Lead uptake by new silica-carbon nanoparticles," European Journal of Chemistry, vol. 4, no. 4, pp. 432-440, 2013.

[33] I. Abbas, H. H. Hammud, and H. Shamsaldeen, "Calix[4]pyrrole macrocycle: extraction of fluoride anions from aqueous media," European Journal of Chemistry, vol. 3, no. 2, pp. 156-162, 2012.

[34] H. H. Hammud, M. E. Mansour, S. Shaalan, E. Khamis, and A. El-Shaar, "Adsorption of mercuric ion by marine algae enteromorpha," International Journal of Applied Chemistry, vol. 2, no. 2, pp. 87-102, 2006.

[35] J. L. Zhou, R. J. Kiff, and J. Chem, "The uptake of copper from aqueous solution by immobilized fungal biomass," Journal of Chemical Technology and Biotechnology, vol. 52, no. 3, pp. 317330, 1991.

[36] A. A. Hamdy, "Removal of $\mathrm{Pb}^{2+}$ by biomass of marine algae," Current Microbiology, vol. 41, no. 4, pp. 239-245, 2000.

[37] A. A. Hamdy, "Biosorption of heavy metals by marine algae," Current Microbiology, vol. 41, no. 4, pp. 232-238, 2000.

[38] P. Ahuja, R. Gupta, and R. K. Saxena, "Sorption and desorption of cobalt by Oscillatoria anguistissima," Current Microbiology, vol. 39, no. 1, pp. 49-52, 1999.

[39] H. Kojima and K. Y. Lee, Photosynthetic Microorganisms in Environmental Biotechnology, Springer, Hong Kong, 2001.

[40] B. Volesky, Biosorption of Heavy Metals, CRC Press, Boca Raton, Fla, USA, 1990.

[41] Y. S. Ho and G. McKay, "Pseudo-second order model for sorption processes," Process Biochemistry, vol. 34, no. 5, pp. 451465, 1999.

[42] G. Y. Yan, T. Viraraghavan, and M. Chen, "A new model for heavy metal removal in a biosorption column," Adsorption Science \& Technology, vol. 19, no. 1, pp. 25-43, 2001.

[43] P. Pavasant, R. Apiratikul, V. Sungkhum, P. Suthiparinyanont, S. Wattanachira, and T. F. Marhaba, "Biosorption of $\mathrm{Cu}^{2+}, \mathrm{Cd}^{2+}$, $\mathrm{Pb}^{2+}$, and $\mathrm{Zn}^{2+}$ using dried marine green macroalga Caulerpa lentillifera," Bioresource Technology, vol. 97, no. 18, pp. 2321-2329, 2006.

[44] P. Lodeiro, J. L. Barriada, R. Herrero, and M. E. Sastre de Vicente, "The marine macroalga Cystoseira baccata as biosorbent for cadmium(II) and lead(II) removal: kinetic and equilibrium studies," Environmental Pollution, vol. 142, no. 2, pp. 264273, 2006.

[45] R. Herrero, P. Lodeiro, C. Rey-Castro, T. Vilariño, and M. E. Sastre de Vicente, "Removal of inorganic mercury from aqueous solutions by biomass of the marine macroalga Cystoseira baccata," Water Research, vol. 39, no. 14, pp. 3199-3210, 2005.

[46] P. X. Sheng, Y.-P. Ting, J. P. Chen, and L. Hong, "Sorption of lead, copper, cadmium, zinc, and nickel by marine algal biomass: characterization of biosorptive capacity and investigation of mechanisms," Journal of Colloid and Interface Science, vol. 275, no. 1, pp. 131-141, 2004.

[47] R. Jalali, H. Ghafourian, Y. Asef, S. J. Davarpanah, and S. Sepehr, "Removal and recovery of lead using nonliving biomass of 
marine algae," Journal of Hazardous Materials, vol. 92, no. 3, pp. 253-262, 2002.

[48] J. R. Rao and T. Viraraghavan, "Biosorption of phenol from an aqueous solution by Aspergillus niger biomass," Bioresource Technology, vol. 85, no. 2, pp. 165-171, 2002.

[49] J. T. Matheickal and Q. Yu, "Biosorption of lead from aqueous solutions by marine algae Ecklonia radiata," Water Science and Technology, vol. 34, no. 9, pp. 1-7, 1996.

[50] B. Volesky and Z. R. Holan, "Biosorption of heavy metals," Biotechnology Progress, vol. 11, no. 3, pp. 235-250, 1995.

[51] Z. R. Holan and B. Volesky, "Biosorption of lead and nickel by biomass of marine algae," Biotechnology and Bioengineering, vol. 43, no. 11, pp. 1001-1009, 1994.

[52] A. M. Abdel-Aty, N. S. Ammar, H. H. Abdel Ghafar, and R. K. Ali, "Biosorption of cadmium and lead from aqueous solution by fresh water alga Anabaena sphaerica biomass," Journal of Advanced Research, vol. 4, no. 4, pp. 367-374, 2013.

[53] Y. H. Yoon and J. H. Nelson, "Application of gas adsorption kinetics I. A theoretical model for respirator cartridge service life," The American Industrial Hygiene Association Journal, vol. 45, no. 8, pp. 509-516, 1984. 

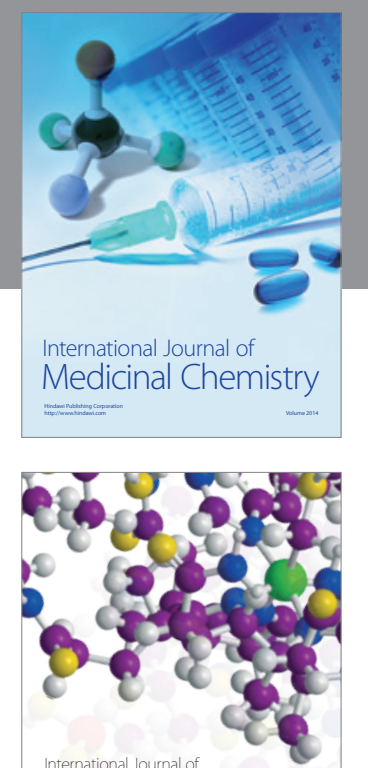

\section{Carbohydrate} Chemistry

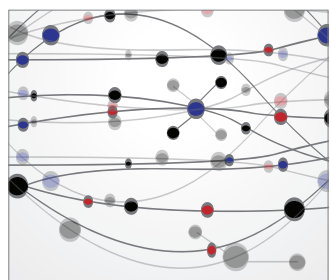

The Scientific World Journal
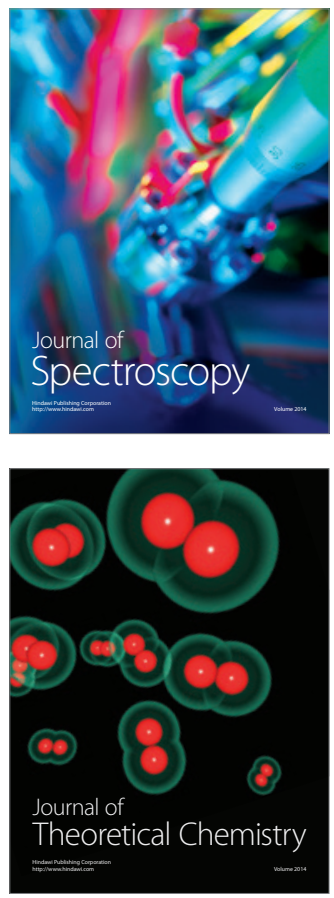
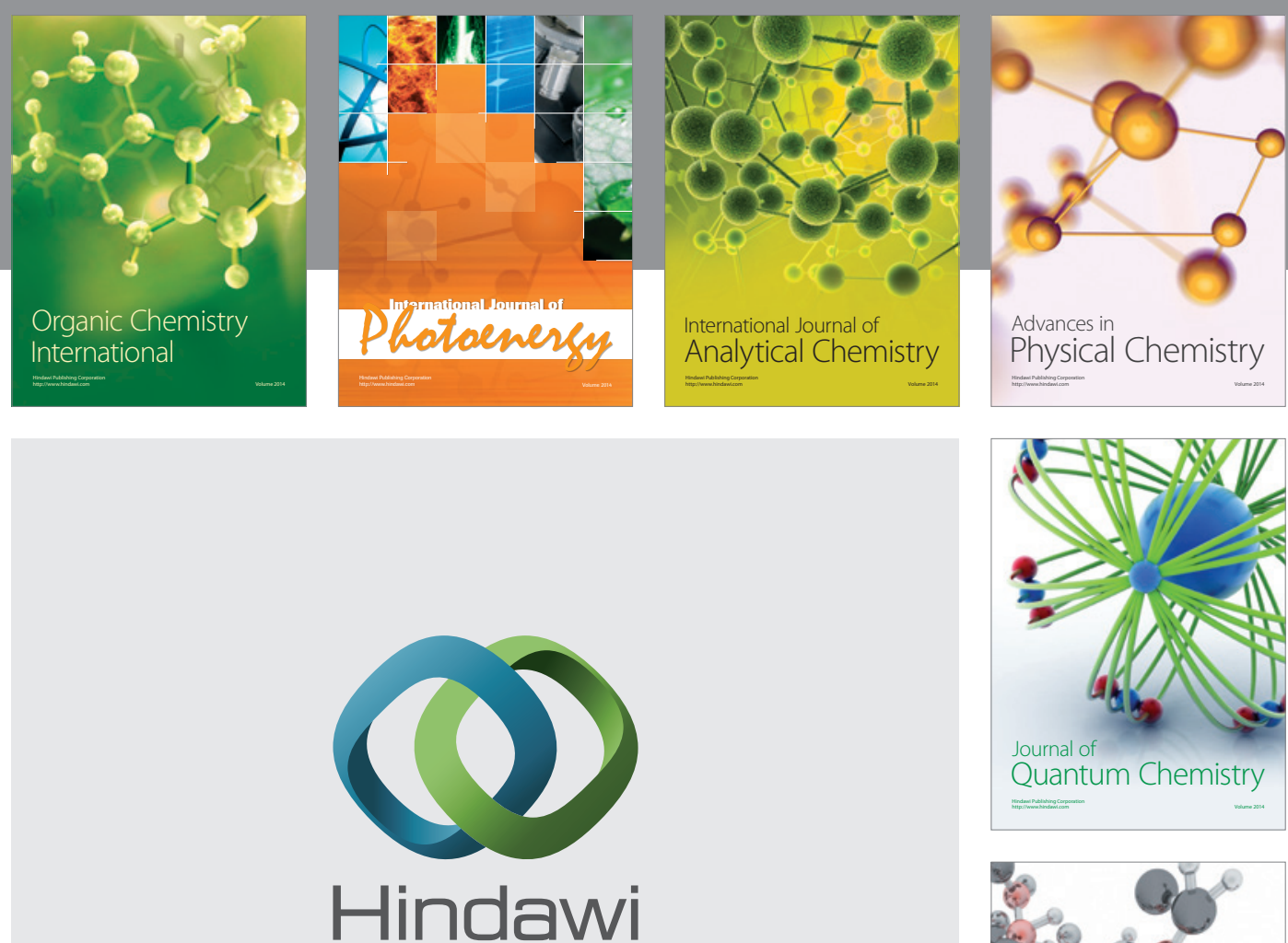

Submit your manuscripts at

http://www.hindawi.com

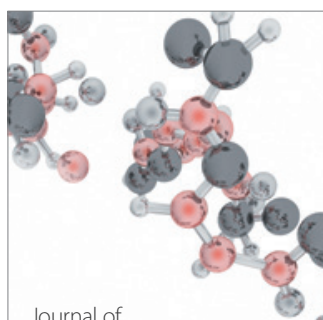

Analytical Methods

in Chemistry

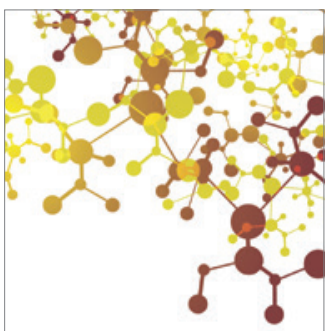

Journal of

Applied Chemistry

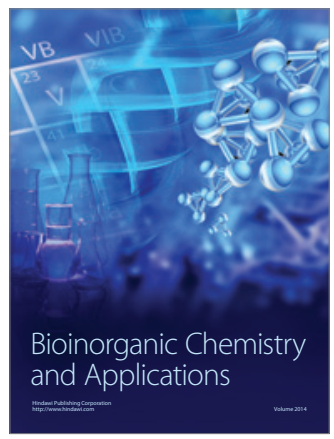

Inorganic Chemistry
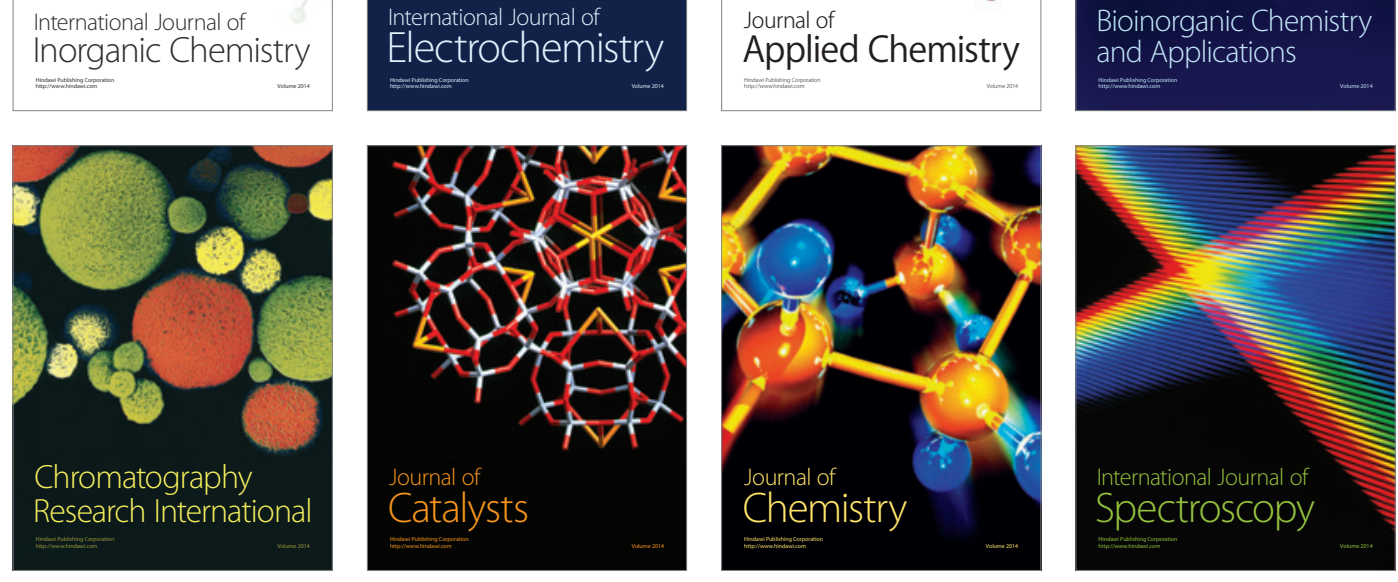